\title{
LENIN E A QUESTÃO AGRÁRIA: pensamento e ação política
}

\section{LENIN Y LA CUESTIÓN AGRARIA: pensamiento y acción política}

\section{LENIN AND THE AGRARIAN QUESTION: thougth and political action}

\author{
DOI: http://dx.doi.org/10.9771/gmed.v12i2.38240
}

Lucas Bezerra ${ }^{1}$

Resumo: Este texto possui por objetivo explorar a relação entre Lenin e a questão agrária no que se refere à elaboração teórica e à ação política por ele levada a cabo. Fruto de pesquisa bibliográfica, dialoga com a produção do autor referente ao tema no período 1899-1922. Afora a introdução e as considerações finais, a exposição encontra-se organizada da seguinte forma: primeiro, situa-se historicamente a realidade econômico social russa entre fins do século XIX e início do século XX; em seguida, discute-se a análise lenineana do desenvolvimento do capitalismo naquele país e o papel assumido pela agricultura; na terceira parte, apresenta-se a concepção de aliança operáriocamponesa; e por fim, um balanço das posições de Lenin sobre a questão agrária e camponesa no contexto da revolução russa e da reforma agrária por ela desenvolvida.

Palavras-chave: Lenin. Desenvolvimento do capitalismo na agricultura. Questão agrária.

Resumen: Este texto tiene como objetivo explorar la relación entre Lenin y la cuestión agraria en Rusia, tanto en términos del pensamiento teórico como de la acción política que llevó a cabo. Fruto de la investigación bibliográfica, dialogamos con la producción del autor sobre el tema en el período 1899-1922. Además de la introducción y las consideraciones finales, la exposición está organizada de la siguiente manera: primero, la realidad social y económica de Rusia está históricamente situada entre finales del siglo XIX y principios del siglo XX; luego, se analiza el análisis de Lenin sobre el desarrollo del capitalismo en ese país y el papel asumido por la agricultura; en la tercera parte, se presenta el concepto de alianza obrero-campesina, originalmente desarrollado por Lenin; en la última parte, contiene un balance de las posiciones de Lenin sobre la cuestión agraria y campesina en el contexto de la revolución rusa y la reforma agraria desarrollada por ella.

Palabras clave: Lenin. Desarrollo del capitalismo en la agricultura. Cuestión agraria.

Abstract: This text aims to synthesize the relationship between Lenin and the agrarian question in Russia, both in terms of the thought he elaborated and the political action he carried out. Fruit of bibliographic research, dialogues with the author's production on the theme in the period 1899-1922. Aside from the introduction and final considerations, the exhibition is organized as follows: first, the Russian social economic reality is historically situated between the end of the 19th century and the beginning of the 20th century; then, Lenin's analysis of the development of capitalism in that country and the role assumed by agriculture are discussed; in the third part, the concept of worker-peasant alliance, originally developed by Lenin, is presented; in the last part, it contains a balance of Lenin's positions on the agrarian and peasant question in the context of the Russian revolution and the agrarian reform it developed.

Keywords: Lenin. Development of capitalism in agriculture. Agrarian issue. 


\section{Introdução}

A memória guardará o que valer a pena. A memória sabe de mim mais que eu; e ela não perde o que merece ser salvo. Eduardo Galeano ${ }^{2}$

Há memórias - as que não perdem o que merece ser salvo - com as quais e por meio das quais gerações e gerações marcham. Nestes casos, a memória confunde-se com o legado: é portadora de ensinamentos, torna-se fonte e põe a história no centro de sua razão de ser. A ampla trajetória de lutas das classes trabalhadoras em todo mundo é exemplo seguro e vivo dessa afirmação. O que se registra no caminho traçado pelas lutas populares é uma frequente referência aos que vieram antes, a gerações passadas que, por meio de suas experiências, acumularam reflexões, métodos de luta, formas de organização, simbologias, erros, acertos. A recorrência elogiosa à memória quer dizer, do nosso ponto de vista, a defesa intransigente da historicidade e em nada se confunde com mitificações. Parece-nos, pois, bastante apropriada para iniciar um texto dedicado a Vladimir I. Ulyanov (1870-1927), conhecido pelo pseudônimo Lenin, reivindicado por gerações em diversas partes do mundo e cujo sesquicentenário de nascimento celebramos neste ano de $2020^{3}$.

Lenin é um clássico por excelência: presença marcante entre os últimos instantes do século XIX e as duas primeiras décadas do século XX, continua a ter muito a dizer quase 'cem anos depois de sua prematura morte aos 53 anos de idade. Sua contribuição à humanidade encontra-se presente em seu legado que a um só tempo é teórico e político - teórico porque em sua vasta há a marca do rigor científico aliado à criatividade e à originalidade extraordinárias; e político em função do destacado papel por ele desempenhado no preparo e na condução da primeira experiência revolucionária de natureza socialista no mundo (a Revolução Russa de 1917). Lenin combinou teoria e política com maestria e por esta razão constituiu-se como expressão avançada do amadurecimento do marxismo, pondo-se a fazer a análise concreta da situação concreta durante toda sua intervenção teórico-política assentada na máxima "sem teoria revolucionária não há movimento revolucionário.” (LENIN, [1902] 2010, p. 81).

Apesar de tamanha grandeza, Lenin nunca ocupou espaço significativo na formação universitária. É pouco lido e muito criticado. Escreveu sobre história, apesar de muitos historiadores jamais terem acessado suas pesquisas; refletiu sobre a economia, embora muitos economistas simplesmente façam de conta que ele sequer tenha existido, no mínimo, e, no limite, a ele atribuam o rótulo de panfletário ou coisa parecida; muito formulou sobre assuntos da ciência política, mas que em nada agrada o mainstream catedrático. Podemos afirmar, sem melindres, que Lenin é academicamente um exilado 4 e as motivações de tal exílio são exclusivamente políticas e ideológicas. Mencionamos este aspecto porque ele é deveras problemático. Menosprezar a contribuição de Lenin ao pensamento social significa condenar com as armas da ignorância parte do que de mais avançado a Modernidade produziu. 
A colossal obra de Lenin demanda ainda hoje um amplo trabalho investigativo. Ao que nos parece, seis grandes eixos que orientaram seu trabalho intelectual:

1) as particularidades da formação econômico-social russa;

2) a questão do desenvolvimento;

3) a questão agrária e camponesa;

4) o método da teoria social;

5) o instrumento partidário, o proletariado e a luta revolucionária;

6) o Estado e as questões teórico-práticas da transição socialista.

Este preâmbulo, ao reforçar a importância multidimensional da obra Lenin, serve-nos para indicar que neste texto temos por objetivo discutir apenas um eixo da obra: o da questão agrária e camponesa. Do início ao fim de sua atividade política e intelectual, a dinâmica processada no espaço agrário esteve no centro das preocupações porque ela representava, a rigor, um elemento fundamental da formação econômico-social russa e da revolução socialista naquele país.

Neste sentido, tentamos estabelecer uma interlocução com elaborações de Lenin que compreendem o período 1899-1922. Esta demarcação justifica-se em função do desenvolvimento de sua obra. 1899 é o ano de publicação de $\mathbf{O}$ desenvolvimento do capitalismo na Rússia, uma de suas mais emblemáticas formulações, a "mais russa" entre todas elas (NETTO, [1979] 1982), e em cujo conteúdo a questão agrária ocupa papel relevante. 1922, por sua vez, serve-nos como marco final porque data desse ano o último texto redigido por Lenin sobre o tema aqui tratado: o relatório por ele apresentado ao IV Congresso da III Internacional Comunista.

Organizamos a exposição em quatro seções, além desta introdução e das considerações finais: $1^{\text {an }}$ ) breve apresentação da realidade econômico-social da Rússia entre fins do século XIX e início do século XX; $2^{a}$ ) o lugar ocupado pela questão agrária na análise lenineana do desenvolvimento do capitalismo na particularidade russa; $3^{a}$ ) síntese da concepção de aliança operário-camponesa; $4^{a}$ ) balanço das posições de Lenin no que tange à questão agrária no contexto da Revolução Russa de 1917.

\section{A Rússia czarista e a questão agrária}

Toda formação econômico-social é portadora de particularidades históricas. Na Rússia não é diferente. No século XVI, enquanto países do continente europeu atravessavam a crise do feudalismo, teve lugar naquele país um regime autocrático, de tradição familiar, denominado czarismo. O czar, chefe de Estado, era o grande líder e para ocupar tal posto recebia o apoio da nobreza. No século XVII, criou-se a dinastia absolutista dos Romanov, fruto da aliança entre a nobreza e a Igreja e que por oito gerações governou a Rússia.

Analisada historicamente, esta configuração até certo ponto intensificou as relações de servidão e, portanto, colocou-se em descompasso em relação aos países próximos que punham em decomposição os traços feudais, substituindo-os por trocas mercantis crescentes. A Rússia encaixava-se, pois, naquilo que 
Engels, na análise da Europa Central e Oriental, definiu como “segunda edição da servidão", 5 em cujas formações econômico-sociais era possível notar a tendência ao reforço de relações pré-capitalistas, a exemplo da corveia, na qual servos e camponeses tinham de prestar trabalho gratuito ao senhor feudal ou mesmo ao Estado. O peso atribuído à corveia em muito se explica em face da pauta exportadora de produtos agrícolas assumida pela economia russa, que cada vez mais transformava a terra do senhor em empreendimento produtivo e comercial.

A considerar que a expansão dos centros urbanos na história da sociedade moderna coincide com o avanço de relações especificamente capitalistas, é de se supor que o espaço agrário ocupava um peso fundamental na Rússia czarista. O campo ainda era o centro. As classes sociais fundamentais, aliás, eram organicamente vinculadas à agricultura, quais sejam: a nobreza e o campesinato.

Os camponeses, embora subjugados agrária, pessoal e juridicamente pelos senhores (Skazkine, 2013), não formavam um todo homogêneo: distribuíam-se em pelo menos duas grandes ou principais categorias, os sob o comando da nobreza e os sob o comando do Estado; não eram economicamente uniformes (haviam camponeses ricos, médios, pobres); uns tinham mais terras, outros menos etc. Os pertencentes ao Estado eram parte do Mir, uma comuna rural com base expressiva no campo russo, "[...]uma comunidade de aldeia que tinha poder sobre as terras dos camponeses e as distribuía entre seus membros segundo diversos critérios que supostamente mantinham certa igualdade entre as famílias camponesas." (OSÓRIO, 2012, p. 111). Embora dominada pelos grandes proprietários, o Mir praticamente organizava os camponeses na sociedade, tendo, diante disso, um importante papel.

Malgrado a heterogeneidade, a realidade vivida pela maioria dos camponeses russos sob os ditames do czar era precária. Os privilégios gozados pela nobreza e pelo clero contrastavam com as condições de reprodução material e espiritual da grande massa da população. A isto o campesinato respondeu de distintas formas em diferentes momentos: ao longo do século XVII predominaram as fugas, às vezes massivas e organizadas; no século XVIII, diversas foram as revoltas camponesas em várias províncias do país; no século XIX, entre os anos 20 e início dos 60, foram mais de mil insurreições (CARVALHO, 2017).

As tensões do período 1820-1860, em particular, são sugestivas da profunda crise então instalada no regime pré-capitalista russo, que não obstante desigual acabava por produzir certa obsolescência no país. Pós-1830, registra-se a introdução da maquinaria e o surgimento das primeiras fábricas, cujo adensamento impunha a necessidade de medidas modernizantes. O desenvolvimento das forças produtivas, mesmo incipiente, exigia assalariamento, qualificação profissional e em última instância a redefinição nas relações de produção e propriedade. Para que o país ingressasse em outro patamar de desenvolvimento, também era necessário elevar a produção agrícola e dar outro destino aos chamados "fundos territoriais", que na literatura econômica refere-se a imensas áreas ainda inexploradas, a exemplo da Sibéria. Na prática, isto significava que era preciso romper - pelo menos em parte - com formas "atrasadas" dessa produção para, em seu lugar - ou combinado a elas -, fazer nascer a industrialização também na agricultura. 
Uma informação histórica importante é a de que a Rússia foi o último Estado do continente europeu a abolir a servidão. Isto somente ocorreu em 1861 - como resultado da crise, evidentemente - e constitui um marco relevante para a apreensão da questão agrária na Rússia. Findada a relação senhor/servo (decretada pelo Imperador Alexandre II, avô do czar Nicolau II), mais de 22 milhões de camponeses foram lançados à sorte de uma nova situação econômico-social. No entendimento de Alexandre II, era "[...] melhor a autoridade libertar os camponeses, do que esperar que eles mesmos se libertem por meio de insurreições." (apud CARVALHO, 2017, p. 04). A medida encaminhada pelo czarismo era, por um lado, preventiva; por outro, representava uma solução conservadora com alguma projeção modernizante.

Neste sentido, todos os esforços deveriam ser mobilizados para não causar desagrado à nobreza fundiária. Assim foi feito. Não se realizou, à época, nenhuma medida de redistribuição de terras, mantendo-se intocada a grande propriedade. O que a "reforma" czarista fez foi estabelecer que os senhores deveriam colocar à venda as terras das quais os camponeses já faziam uso e posse. Em contrapartida, o Estado comprometia-se a ressarcir os senhores com uma indenização pela venda das terras aos camponeses. Em relação a estes, estabeleceu-se uma fase de transição:

não adquiririam o direito de propriedade privada sobre a terra comprada, permanecendo como membros de uma comuna e de um grupo doméstico. A comuna continuava responsável pela distribuição da terra aos grupos domésticos e seus integrantes. Os membros da comuna pagariam um imposto coletivo [...] e ninguém poderia renunciar às obrigações de sua comuna, mesmo estando incluído na minoria que conseguia permissão para residir em outro lugar. Entre as outras obrigações mantidas pela comuna, estava assegurar o pagamento do débito contraído com o Estado pelas terras adquiridas dos senhores. Este estágio transitório, que deveria ser breve, perdurou por muito mais tempo que o previsto. (OSÓRIO, 2012, p. 112).

As condições das quais a grande parcela dos camponeses dispunha para viabilizar essa alternativa era mínima. O que houve, na maior parte dos casos, foi uma violenta expropriação de parcelas de terras dos camponeses. Conservou-se o latifúndio e levou às ruínas muitas explorações camponesas. Pôs-se em marcha, em consequência, uma diversificação cada vez maior do campesinato russo: grande parte acumulou dívidas; malgrado a preservação do Mir, pagar pela terra passou a ser uma realidade (otrę̧ki); processou-se um êxodo do campo para as cidades (em poucas décadas, Moscou ganhou o auto-explicativo apelido de "grande aldeia"). Sinteticamente, a reforma de 1861 causou insatisfação e transtornos objetivos aos camponeses.

Há de se levar em consideração que no trânsito entre os séculos XIX e XX 80\% da população do país era de camponeses. Qualquer desfecho para a situação russa dificilmente passaria por fora deles. Como era de se esperar, o agravamento da crise agudizou também as contradições sociais: o empobrecimento da grande massa, a elevação da fome, a limitação do acesso à terra, o inchamento das cidades, enfim, um conjunto de elementos gerou uma instabilidade interna cada vez maior. À crise econômica e política interna aliou-se uma crise no âmbito das relações exteriores, fruto da guerra entre o Império Russo e o Japão. 
Desenvolveu-se, neste cenário, o movimento revolucionário de 1905, por Lenin considerado o germe da Revolução Russa e cuja agenda política imediata era a seguinte: anistia (muitos estavam exilados em função de mobilizações anteriores), liberdades civis, melhores salários, redistribuição da terra, convocação de Assembleia Constituinte a ser eleita por sufrágio universal.

Este foi o conteúdo apresentado no documento portado pela marcha de milhares no conhecido "Domingo Sangrento". Assim concluía a ingênua (mas aguerrida) petição remetida ao czar: "Senhor: não recuses ajudar o teu povo. Derruba a muralha que te separa do teu povo! Ordena que seja dada satisfação aos nossos pedidos, ordena-o publicamente e tornarás a Rússia feliz; se não, estamos prontos a morrer aqui mesmo. Só temos dois caminhos: a liberdade e a felicidade ou o túmulo." (apud LENIN, 1917, s/p) O movimento, porém, foi fortemente reprimido pelo aparato armado czarista, que impôs uma derrota às forças revolucionárias, a estas respondendo com prisões, assassinatos e exílios. À época, Lenin estava exilado e os relatos das sublevações a ele foram feitos por um padre que cumpriu destacado papel no "Domingo Sangrento".

O poder autocrático, por sua vez, com receio de que mobilizações populares daquela natureza voltassem a se repetir, tratou de encaminhar algumas medidas paliativas. $\mathrm{O}$ foco foi o setor agrário. $\mathrm{O}$ responsável pela formulação de tais medidas foi Peter Arkadievich Stolypin, filho e fiel representante da aristocracia fundiária e primeiro-ministro do Império Russo entre 1906 e 1911. Segundo Prestes e Prestes (2020), Stolypin foi um dos mais destacados dirigentes da repressão estatal contra a Revolução de 1905. Ele, na perspectiva de redefinir parcialmente as relações agrárias e agrícolas, "[...] resolveu reverter o sistema comunal e introduziu o conceito de propriedade privada, declarando que todo camponês, que assim desejasse, poderia deixar a comuna e exigir dela uma parte de terra para cultivar para si e sua família. Com a morte do camponês, a terra seria herdada por seus filhos.” (PRESTES; PRESTES, 2020, p. 2). Sua movimentação baseava-se em contribuir com a introdução de formas capitalistas no campo e, para tanto, dar "assistência estatal" ao seu desenvolvimento, o que levou o regime a fortalecer seus laços com os camponeses ricos (kulaks) que mais adiante transformaram-se em capitalistas agrários.

Fato é que a política aplicada pelo primeiro-ministro em nada alterou a distribuição da propriedade fundiária, limitando-se tão somente a duas novidades: i) o estabelecimento da propriedade privada; ii) a herança vinculada (Carvalho, 2017). Estas, no entanto, abriram uma janela para o desenvolvimento do capitalismo na agricultura russa. Tanto é que a existência de franjas de classe próprias do capitalismo, como a burguesia agrária, a pequena burguesia agrária e o proletariado agrícola, somente emergiram na Rússia, a rigor, após a reforma aplicada por Stolypin.

Resumidamente, a realidade russa na crise do Império demonstrava-se complexa em demasia e isto se deve sobremodo à combinação acelerada de práticas ou relações aparentemente duais. Nesse emaranhado, a agricultura indiscutivelmente era um aspecto decisivo assim como o era seu sujeito principal, o campesinato, que por um lado carregava em suas costas o peso da servidão e, por outro, as incertezas do futuro próximo, que já se anunciava problemático por razões como a concorrência e a monopolização da terra. 
Lênin inseriu esta importante questão no centro de suas elaborações. $\mathrm{O}$ triunfo do processo revolucionário na Rússia exigia uma interpretação acertada das particularidades da questão agrária na Rússia. Este era um debate central do movimento comunista entre fins do século XIX e início do século XX.

\section{A questão agtária em $O$ desenvolvimento do capitalismo na Rússia}

Lenin estava convencido, em meio àquelas circunstâncias histórico-conjunturais, de que era preciso construir uma rigorosa análise da formação econômico-social da Rússia à luz da teoria social de Marx para, a partir dela, isto é, por meio da identificação dos caracteres gerais e particulares do país em determinado momento, traçar os mais viáveis rumos para construção e êxito do processo revolucionário. Em 1899, o jovem Lenin, com sequer trinta anos de idade completos, enquanto estava no exílio, publica com o pseudônimo Vladimir Ilyin $\mathbf{O}$ desenvolvimento do capitalismo na Rússia (DCR), uma obra densa, resultado de uma pesquisa fortemente assentada em dados empíricos em torno dos quais ele desenvolve reflexões criativas, insólitas e minuciosas.

Florestan Fernandes, na introdução de um volume por ele organizado intitulado Lenin: Política (Fernandes, 1989), sistematiza que DCR realça pelo menos três grandes qualidades teóricas do autor: em primeiro lugar, o consistente domínio do aporte categorial da crítica da economia política; em consequência a isto, em segundo lugar, a capacidade na elaboração de uma tese não-eclética, ortodoxa em termos de fidelidade ao método (LUKÁCS, [1923] 2003); e em terceiro lugar, a fuga a esquematismos inférteis, revelando, em última instância, uma apropriação consistente do marxismo para a análise de uma formação social. No mesmo raciocínio, José Paulo Netto ([1979] 1982), em introdução à edição brasileira de $D C R$, sugere que a relevância ou mesmo o valor maior da elaboração lenineana de 1899 não se restringe à abundância de informações econômicas, culturais e políticas sobre a Rússia, mas à "[...] efetiva comprovação de que, face a irredutível particularidade que constitui cada formação econômico-social, o método se recria no confronto com a empiria, cuja aparente opacidade é ultrapassada e dissolvida na captação de sua essência movente" (NETTO, [1979] 1982, p. 21).

O principal objetivo de Lenin em DCR consiste em analisar em perspectiva histórica a situação concreta da Rússia e, em particular, o processo de formação de um mercado interno para o capitalismo; e o faz também a fim de responder a interlocutores situados em distintos pólos da luta política, à direita e à esquerda, mas especialmente aos "populistas"7. 
Considerados os riscos de toda síntese, DCR pode ser resumido na seguinte tese: malgrado o peso da servidão, o capitalismo estava a desenvolver-se na Rússia comportando, em seu interior, formas particulares e, por assim dizer, não-clássicas. Em 1894, quando da redação de Quem são os “amigos do povo" e como lutam contra os social-democratas?, Lenin já argumentava, ainda que com poucos dados, que estava se processando um desenvolvimento capitalista na Rússia e que este desenvolvimento havia sido impulsionado pela reforma de 1861. Em DCR ele não somente retoma este fio condutor como o põe em um patamar analítico muito mais complexo e rico em termos de dados, além de delimitar explicitamente o objeto de sua investigação: o processo de formação do mercado interno para a grande indústria na Rússia.

O que o conduz a estas conclusões, ao que nos parece, é i) a complexa inter-relação mercado interno $8 /$ mercado externo $^{9}$ ali processada, bem como ii) as alterações nas dinâmicas campo/cidade e indústria/agricultura, presentes na desintegração do campesinato, na progressiva tendência à proletarização rural, nos progressos técnicos nos estabelecimentos agrícolas. Ambas, na visão de Lenin, conferiam conteúdo ao "desenvolvimento desigual" na Rússia10 (MEDEIROS; BEZERRA, 2019).

Segundo ele, a decomposição do campesinato e seu rearranjo em novas frações de classe já não era resultado de relações pré-capitalistas senão capitalistas, tendência reforçada pelo fato de a produção agrícola do país, àquela altura, destinar-se já majoritariamente ao mercado. Todas estas características são posteriores à reforma de 1861, cujo resultado articula a preservação sobre os camponeses de caracteres feudais e a penetração crescente do capitalismo mediante o crescimento do capital industrial (com o capital comercial e usurário a ele associado) e de outros elementos econômicos inerentes ao modo de produção capitalista, como a monopolização e a concorrência.

Assim, a questão agrária está no centro dos dilemas de então e, por esta razão, adquire preponderância analítica em $\mathbf{O}$ desenvolvimento do capitalismo na Rússia e, de certo modo, atravessa o conjunto do livro. A este respeito, há pelo menos três questões centrais que estavam colocadas às forças revolucionárias na Rússia daquele período:

1) Em que o desenvolvimento das forças produtivas recompunha as classes sociais e as lutas de classes na Rússia?

2) Que papel a agricultura estava a cumprir no processo de formação e consolidação do mercado interno?

3) Que posição política deveria ser tomada em relação ao Mir?

A estas perguntas Lenin respondeu com fundamento histórico nas particularidades da sociedade russa e delas extraiu sínteses para a luta política. Apresentemos brevemente, uma a uma, as respostas por ele desenvolvidas.

Sobre a primeira questão: Lenin identifica uma recomposição no âmbito das classes e frações de classes. Não se tratava de uma mera diferenciação interna na sociedade pré-capitalista, mas de um redesenho que arrastava consigo classes sociais características do desenvolvimento do capitalismo, em geral, e do desenvolvimento do capitalismo na agricultura, em particular. 
Formava-se ali, na processualidade da crise do czarismo - e ao mesmo tempo como efeito das medidas por ele encaminhadas, i) uma burguesia agrária (até então representada na figura do camponês rico; ii) uma fração de produtores independentes (em alguns textos da literatura especializada tratados como "pequena burguesia agrária"), com terra para plantar e colher e que já praticavam uma agricultura mercantil; iii) os arrendatários capitalistas, também pertencentes ao capital industrial e/ou comercial, cuja renda da terra constituía uma de suas importantes formas de rendimento; iv) um proletariado agrícola em franca expansão, grande parte com pequenos lotes de terra; v) uma grande massa de camponeses semterra, inteiramente apartados do meio de produção universal capaz de lhes viabilizar a reprodução material; vi) os estratos médios do campesinato, intermediários entre os camponeses ricos e os proletários rurais, mas cuja grande parcela migrava e punha sua força de trabalho à disposição para o assalariamento (OSÓRIO, 2010).

Portanto, as alterações no âmbito das classes eram tanto em relação aos "de cima" quanto aos "de baixo". Todavia, esta reconfiguração não rompeu com métodos arcaicos no campo. O emprego de progressos técnicos modernizantes procedia apenas nas grandes fazendas senhoriais, que vinham praticando novas culturas agrícolas. Por outro lado, a grande propriedade mantinha os camponeses sob o seu jugo, preservando métodos atrasados, semifeudais. Em algumas regiões predominavam formas semiservis, em outras estas se combinavam às capitalistas, em outras, ainda, como o Leste e o Extremo Sul, consolidavam-se formas especificamente capitalistas. Às vezes, numa mesma unidade produtiva, mesclavam-se formas modernas e arcaicas. A um só tempo, expandia-se o assalariamento da força de trabalho no campo e o êxodo rural - aliás, duas ilustrações da maior importância à apreensão das transformações econômico-sociais ali processadas. A este respeito, as passagens abaixo são ilustrativas:

Os operários agrícolas, que afluem em massa ao Sul, provêm das camadas mais pobres do campesinato. Dentre os que chegam à província de Kherson, 70\% não têm condições de comprar uma passagem de trem e fazem o trajeto a pé. (LENIN, [1899] 1982, p.155).

Verifica-se que os operários assalariados [...] abandonam as regiões onde o regime da servidão era mais desenvolvido por aquelas onde ele era mais débil, trocando os locais onde é sólido o sistema de pagamento em trabalho por aqueles em que é frágil e onde o capitalismo atingiu um alto grau de desenvolvimento. Noutros termos: eles fogem do trabalho 'semilivre', procurando um trabalho livre. Seria um erro considerar que esse êxodo se reduz ao abandono de regiões com alta densidade populacional, trocadas por outras, com menor densidade. O estudo das migrações revelou algo original e importante: em muitas regiões, a saída de operários ocorre em números tão elevados que provoca redução na oferta de mão-de-obra [...]. O número de operários agrícolas nômades, na Rússia, certamente é superior a 2 milhões. Essa massa 'camponesa' que abandona sua casa e seu pedaço de terra [...] evidencia o gigantesco processo de transformação dos pequenos agricultores em proletários rurais e revela a enorme demanda de mão-de-obra assalariada do capitalismo agrário em desenvolvimento. (LENIN, [1899] 1982, p. 154).

É preciso ponderar, nessa direção, que em momento algum Lenin analisou estes fenômenos tanto o da proletarização agrícola quanto do êxodo rural - sob um ponto de vista maniqueísta, esquerdista ou principista, como o faziam os "populistas"11. Nosso pensador estava ciente de que aquele processo de 
desenvolvimento do capitalismo na agricultura comportava, contraditoriamente, um conteúdo progressista. Ele chega a afirmar que o capitalismo agrário na Rússia constitui uma força progressista notável porque "[...] rompeu, pela primeira vez, com o caráter restrito de classe da posse da terra [...] [e] sacudiu pela primeira vez a estagnação secular de nossa agricultura.” (LENIN, [1899] 1982, p. 203).

Em vista disso, malgrado o que há de "sombrio" no desenvolvimento capitalista, tornava-se possível uma ruptura com barreiras particularistas, provincianas e medievais, o que para Lenin significava um feito extraordinário ${ }^{12}$. Sua perspicácia e seu rigor teórico-metodológico, associados às lições da prática política, o levaram a concluir que o deslocamento de grandes contingentes populacionais para as cidades ${ }^{13}$ e o assalariamento no campo poderiam, em termos tendenciais, originar contradições novas às quais os revolucionários tinham o dever de estar atentos na perspectiva de fazer avançar o processo revolucionário. O exercício de decifrar a reconfiguração das classes na Rússia não era, afinal de contas, questão de tratado sociológico, econômico ou coisa parecida. Não é a isto que se destina DCR. Inversamente, o que lhe interessava era explicar as repercussões desse processo no âmbito das lutas de classes. Novos personagens haviam entrado em cena e suas consequências políticas eram incontornáveis.

Sobre a segunda questão: concomitante à nova "morfologia" das classes intensificava-se a produção capitalista, a divisão social do trabalho e, consequentemente, formava-se o mercado interno.

O mercado interno caracteriza-se, do ponto de vista aqui adotado, pelo processo de expropriação (separação do produtor direto dos meios de produção e de subsistência) que caracteriza a passagem da produção mercantil simples à produção capitalista. Diz respeito ao grau de desenvolvimento do capitalismo e historicamente consolida-se em duas direções: de um lado, "os meios de produção [...] convertem-se em capital nas mãos dos seus novos proprietários, passa a servir à produção de mercadorias e, consequentemente, convertem-se eles mesmos em mercadorias". De outro, "os meios de subsistência, para o pequeno produtor, tornam-se elementos materiais do capital variável [...] esses meios [...] transformam-se agora também em mercadoria, ou seja, criam um mercado interno para artigos de consumo." (LENIN, [1899] 1982, p. 32). A especialização do trabalho e a fusão entre indústria e agricultura no interior da totalidade de um mesmo processo produtivo são inerentes a esta tendência.

Nesse sentido, era de importante identificação o papel a ser cumprido pela agricultura no novo ordenamento que compreendia a formação do mercado interno. A agricultura crescentemente transformava-se em ramo produtor de mercadorias. A burguesia agrária “[...] dinamizava o mercado de duas maneiras: primeiro, estimulando o mercado dos meios de produção ${ }^{14}[. .$.$] , porque o campesinato rico$ se esforçava por converter em capital os meios de produção que 'acumulava'; segundo, pelo fortalecimento do mercado de consumo pessoal." (OSÓRIO, 2010, s/p). Com a criação do mercado interno, generalizava-se o consumo também na agricultura, mas em condições evidentemente diferentes: i) o assim chamado campesinato rico (kulaks) era a própria burguesia agrária; ii) os camponeses médios, endividados, ao engrossar as fileiras do proletariado a cada safra ruim, tendiam a desaparecer; iii) o proletariado rural consumindo produtos de qualidade ruim; e iv) os camponeses sem-terra que, quando muito, a depender da sorte, também tinham acesso a produtos ruins ou à fome limitavam-se. Com a 
desintegração do campesinato tradicional e a formação de novos tipos de população rural, sobressaíram-se os extremos: a burguesia agrária, de um lado; o proletariado rural e os camponeses sem-terra, de outro. A qualidade da luta de classes no campo já não era a mesma de tempos atrás.

Por conseguinte, não se pode explicar o papel da agricultura na formação do mercado interno russo se não se considera que este processo, ao reproduzir a totalidade do capital social e a compensação de componentes isolados do produto social, vincula-se à universalização do modo de produção capitalista. Consolidado o mercado interno, a tendência natural é a de "procurar" um mercado externo. Lenin articulou as determinações entre o interno e o externo com maestria. Ciente de que "[...] um país capitalista sem comércio exterior é impensável", avaliava como progressista a articulação mercado interno/externo, dado que ela destruía "[...] o isolamento e o particularismo [...] dos antigos sistemas econômicos, reunindo todos os países do mundo numa só totalidade econômica." (LENIN, [1899] 1982, p. 31).

Em síntese, o "problema" da constituição de um mercado interno na Rússia, tanto na agricultura quanto na indústria, representou um passo do desenvolvimento capitalista naquele país, possibilitando tensões com os caracteres pré-capitalistas existentes. A despeito do caráter "desigual" ou "anárquico" desse desenvolvimento, ele invariavelmente trouxe consigo alterações nas relações técnicas de produção e, no global, nas relações sociais de produção, fazendo emergir uma recomposição das classes sociais que, por sua vez, provocava alterações qualitativas nas lutas de classes. Esta tese, no cômputo geral, era refutada pelos populistas, para os quais, míopes, o desenvolvimento do capitalismo na Rússia era lento em demasia ou, na pior das hipóteses, ainda estava por vir. Incorriam, assim, em estreitas conclusões moralizantes e a-históricas por não considerarem "[...] os diversos grupos que participam da produção como criadores dessas ou daquelas formas de vida e não se coloca como objetivo a apresentação de todo o conjunto das relações econômicas e sociais como resultante das relações existentes entre esses grupos, cujos interesses e papéis históricos são diferentes.” (LENIN, [1899] 1982, p. 375).

Sobre a terceira questão: a polêmica com os populistas continua, por motivos similares, no debate em relação ao futuro da comuna rural (Mir). Para eles, o Mir continha o embrião da futura sociedade socialista e o principal argumento que embasava essa defesa era o dos traços de coletivismo que ali haviam. Orientados por esse raciocínio, julgavam como regressiva a dissolução de relações comunitárias e o ingresso da Rússia no "caminho Ocidental”.

Lenin não só se opõe ao principismo populista como comprova que a lógica da servidão inexoravelmente fazia-se presente na comuna rural. Do seu ponto de vista, a posição dos populistas limitava-se, por um lado, a querer identificar "vantagens" em relações arcaicas, e, por outro, a negar as contradições do movimento histórico. Não bastasse isso, àquela altura a defesa intransigente do Mir representava uma verdadeira corrida contra o tempo (Fernandes, 1982), já que o desenvolvimento do capitalismo na agricultura vinha relegando um papel cada vez menos relevante à comuna rural. Ao contrário dos populistas, Lenin "não via na desintegração da comuna camponesa um limite para a formação do mercado interno e para a evolução do capitalismo" (SILVA, 2011, p. 123), pois o divórcio 
entre produtores diretos e meios de produção e de subsistência vinculava-se à divisão do trabalho e alicerçava o desenvolvimento capitalista.

O Mir, nessa acepção, não era uma ilha isolada ou um paraíso sem contradições. Também nele penetravam as relações sociais capitalistas. Com o fim da servidão, em 1861, as terras distribuíram-se em duas partes: uma sob o comando dos antigos senhores e outra sob o comando do Mir. Acontece que as terras do Mir eram partilhadas entre os seus, mas isto era reordenado a partir da compra de terras ou do arrendamento de uns camponeses por outros. Os "outros", no caso, eram os que dispunham de melhores condições para a produção ou mesmo negociação em relação à terra. Porém, grande parcela do campesinato que vivia na comuna conseguia reproduzir-se, inicialmente, empregando mais trabalho familiar, mas logo demandava acréscimo de força de trabalho, levando à contratação de trabalhadores assalariados e, mais adiante, ao emprego de animais de tração (SILVA, 2011). Disso se deve reter, no essencial, que o desenvolvimento do capitalismo na agricultura russa também "[...] se desenvolve entre os 'membros das comunidades rurais' e os célebres 'laços comunitários' se ajustam perfeitamente aos grandes detentores.” (LÊNIN, [1899] 1982, p. 51). Ao fim e ao cabo, o Mir também explorava o camponês e seu desaparecimento constituía uma necessidade política.

Enfim, parece-nos viável concluir que as três questões aqui brevemente apresentadas possuem entre si um fio condutor, uma relação de unidade. A recomposição das classes na agricultura, a expansão do mercado interno e o futuro da comuna camponesa determinam-se reciprocamente na análise da formação econômico-social russa no final do século XIX. A síntese histórica a que chega Lenin em DCR permitiu-lhe concluir que a agricultura representava a mais sólida e profunda base do capitalismo naquele país, cujo campesinato, em frenéticas mudanças internas, deveria ser considerado como parte fundamental da estratégia capaz de libertar a Rússia da autocracia czarista.

\section{A aliança operário-camponesa}

Lenin avaliava que a autocracia czarista e o poder do latifúndio condenavam a Rússia ao atraso e as massas (o campesinato) a miseráveis condições de vida. Na passagem do século XIX ao século XX, as forças revolucionárias do país defrontaram-se e enfrentaram a seguinte questão: como construir uma sociedade socialista num país czarista, arcaico, pré-capitalista? Um debate complexo e sobre o qual as formulações do movimento comunista internacional ainda eram um tanto insuficientes, por um lado, e por outro não encontravam correspondência, pelo menos em parte, à situação concreta da Rússia. 
Em 1903 ocorre o II Congresso do Partido Operário Social-Democrata Russo (POSDR, fundado em 1898, do qual Lenin era dirigente) e, em sua programação, o debate relativo à presença dos resquícios feudais na Rússia e mesmo sobre o caráter do desenvolvimento capitalista naquele país. As ideias contidas em DCR certamente influenciaram a dinâmica congressual e isto se deve, sobremodo, às consequências políticas sugeridas pela obra. De certo modo, as formulações de Lenin punham em questão o parco acúmulo do movimento comunista internacional e, em específico, do Partido Social-Democrata da Alemanha (SPD), que exercia influência sobre o POSDR e possuía entre seus dirigentes um dos mais expoentes intelectuais marxistas da época, Karl Kautsky.

O debate marxista feito pelo SPD e pelo próprio Kautsky sobre a questão agrária apontava, com referência em poucas indicações de Marx e Engels, que o campesinato tendencialmente desapareceria no curso do desenvolvimento capitalista. Isto posto, seria desnecessário, por parte do proletariado, mobilizar forças em defesa do camponês transfigurado em pequeno produtor e atenção deveria centrar-se exclusivamente ao proletariado rural (OSÓRIO, 2013). Afora isso, o precário (em termos científicos) debate marxista "tradicional” sobre a questão camponesa estava em larga medida baseado em experiências históricas anteriores, como a Comuna de Paris (1871), na qual o campesinato engrossou as fileiras da contrarrevolução.

Lenin, entretanto, fugiu de conclusões fechadas para analisar a formação econômico-social russa. Levou às últimas consequências a tese segundo a qual a Rússia era um caso particular e nela o campesinato poderia cumprir papel decisivo no processo revolucionário não somente porque era um segmento massivo mas porque sua exigência objetiva, a eliminação do latifúndio, não poderia ser levada adiante pela burguesia. Em função disso, o proletariado teria de disputar o campesinato e a posição mais consequente a ser tomada pelo POSDR seria o apoio às reivindicações camponesas.

Aí residem os primeiros passos de uma das mais significativas elaborações lenineanas: a aliança operário-camponesa, cujo conteúdo tem influenciado largamente a organização revolucionária das classes trabalhadoras desde sua elaboração. A rigor, essa concepção é uma das mais influentes do marxismo no século XX dada sua consistência teórica e sua presença em diversos processos de transição ao socialismo, a exemplo de China (1949), Cuba (1959) e Nicarágua (1979).

Ao que nos parece, a primeira vez em que Lenin se aproxima da ideia de aliança operáriocamponesa é no já mencionado Quem são os "amigos do povo" e como lutam contra os socialdemocratas?, publicado em 1894. Nesse texto, também em polêmica com os populistas, Lenin remete à luta contra a opressão burguesa e latifundiária e destaca o potencial explosivo de uma aliança entre operários e camponeses empenhados na derrubada do czarismo. Esta ideia passa, a partir de então, a se fazer recorrente nas formulações de nosso autor. A ela ele regressa, de modo cada vez mais lapidado, em Aos pobres do campo (1903), no Programa Agrário da Social-Democracia na Primeira Revolução Russa e no conjunto de escritos políticos do período 1917-1922 (a exemplo de A revolução proletária e o renegado Kautsky, de 1918). 
Considerados os limites deste texto e a proposta de síntese a que se dedica, parece-nos suficiente assegurar que a concepção de Lenin sobre a aliança operário-camponesa pode ser resumida nos seguintes termos: consideradas as condições histórico-particulares da Rússia, é preciso que o proletariado junte-se aos camponeses e construa um programa que corresponda às suas reivindicações.

Em Aos pobres do campo, ele põe o problema de modo a concluir que o campesinato, sem se unir ao operariado, jamais poderá desvencilhar-se por inteiro da servidão e da miséria (LÉNINE, [1903] 1984). Nesse sentido, a unidade é marcada por uma relação de reciprocidade: tanto o operariado precisa aliar-se ao campesinato para dar consequência à revolução quanto o campesinato demanda o apoio dos operários na luta contra os grilhões da servidão. Com o êxito dessa unidade, viabilizar-se-ia o definhamento da burguesia e do latifúndio mediante o confisco das terras, atendendo assim à principal demanda dos camponeses.

Sendo este o indicativo teórico-prático, a Revolução de 1905 apenas o ratificou, tendo em vista que ela pôs os bolcheviques (ainda com presença ínfima no campo e, neste ponto, sobressaíam-se os socialistas-revolucionários ${ }^{15}$ ) diante de amplos e massivos levantes camponeses, complementados por diversas greves nos principais centros urbanos e industriais em praticamente todas as regiões do Império Russo. A ação dos camponeses, com potencial revolucionário, impressionou ainda mais o POSDR. Em razão disso, Lênin passou a tratar com grau cada vez maior de seriedade o programa agrário dos bolcheviques. Ora, se se presencia uma conjuntura na qual os camponeses emplacam uma luta contra o latifúndio, ocupando-o e expropriando-o, entende-se que a tarefa do partido bolchevique consiste em melhor ajustar sua linha política de modo a, por meio de aliança operário-camponesa, construir força própria e acumular a força social capaz de derrotar a autocracia czarista.

Nesse sentido, a definição de uma palavra de ordem não era algo simples. A resposta mais imediata, por parte dos bolcheviques, seria a expropriação do latifúndio e a formação de fazendas de propriedade coletiva que desenvolvessem a exploração agrícola. Esta "saída", no entendimento de Lenin, não encontraria correspondência às expectativas e ao ânimo dos camponeses naquelas circunstâncias e poderia ser muito mais fator de dissolução do que qualquer outra coisa. Lênin então passou a propor, do ponto de vista organizativo, a criação de comitês camponeses, capazes de dar melhor consequência política às ocupações de terras da Igreja, do Estado e dos latifundiários em geral, além de servir como catalisador da relação política com o operariado. Entretanto, ainda que esta proposta encontrasse maior aderência no seio do campesinato, ela deixava uma questão central em aberto: o que fazer com as terras confiscadas? Distribuí-las entre pequenos proprietários individuais? Nacionalizá-las? Na proposta original de Lenin, caberia aos comitês camponeses somente administrar as propriedades confiscadas até a instauração de uma possível Assembleia Constituinte. 
Dois anos depois, em 1907, quando da redação de O programa agrário da social-democracia na primeira revolução russa: 1905-1907, Lênin retomou a urgência e atualidade da aliança operáriocamponesa. Sintetizou, "desta vez com maior nitidez, duas possibilidades de desenvolvimento do capitalismo no campo[...]: a via prussiana, onde o latifúndio feudal transforma-se gradativamente no latifúndio [...] burguês sob a batuta do Estado; e a via americana, onde os camponeses destruíam os grandes latifúndios, dividindo as terras em pequenas fazendas." (SOUSA, 2017, p. 51).

Sinalizar havia mais adequada às particularidades da Rússia exigia, antes, responder à seguinte questão: qual a contradição principal a ser enfrentada pelo primeiro estágio da Revolução Russa?

Aí entra o debate em torno da processualidade daquela Revolução. A Rússia, como se sabe, não havia experimentado uma revolução democrático-burguesa e, na visão de Lenin, tarefas características desse "tipo" de revolução tinham de ser num primeiro momento levadas adiante naquele país onde o "atraso" ainda era uma força significativa. Era preciso subtrair quaisquer práticas econômicas, políticas ou jurídicas que constituíssem um empecilho ao desenvolvimento das forças produtivas e, nessa direção, a Revolução Russa seria num primeiro momento democrático-burguesa no sentido de seu conteúdo econômico e social.

Para Lenin ([1907] 1980), a luta dos camponeses contra o latifúndio feudal informava a contradição principal na primeira fase da revolução russa. Por meio dessa conclusão, Lenin admite que a via americana, no tocante à questão camponesa, era mais adequada à particularidade russa naquele período. A pauta da nacionalização da propriedade do solo deveria, deste modo, constar no programa do partido bolchevique.

Nesse sentido, nas condições de 1905, a Revolução Russa não poderia ser mais que uma revolução democrático-burguesa, mesmo não clássica, por determinação da contradição principal que assolava o país. A Lenin não resta dúvida quanto ao fato de que a questão agrária, em função de seu peso, determinava a dimensão nacional da revolução democrático-burguesa na Rússia (LENIN, [1907] 1980). A burguesia, porém, não dispunha de condições para fazer valer sua hegemonia sobre as demais classes sociais e, em função disso, mantinha umbilical relação com czarismo. O proletariado, por sua vez, ainda era uma força incipiente. Habilidosamente, e defendendo o caráter ininterrupto da Revolução, o partido bolchevique compreende que construir a hegemonia operária na Rússia necessariamente demandava a incorporação das massas camponesas. 
Esta aliança - com foco nos camponeses pobres - poderia extinguir por inteiro o regime de servidão, modernizar a agricultura e nacionalizar a propriedade da terra. Sem deixar de considerar a luta de classe entre a burguesia agrária e o proletariado rural, Lenin "assinalava a necessidade de a luta no campo se desenvolver em dois planos: o plano da luta camponesa contra os resquícios do feudalismo e o plano da luta de classes entre os capitalistas agrários e os assalariados agrícolas." (OSÓRIO, 2013, p. 121). Ambos, conjuntamente, poderiam emplacar em melhores condições a luta e o delineamento de uma política de alianças que pudesse resultar na instalação de uma Assembleia Constituinte e de uma República Democrática com governo provisório (com a débil burguesia liberal, inclusive) que expressasse um regime político de ditadura democrática do proletariado e dos camponeses. No interior desse governo, ainda na primeira fase da Revolução, o proletariado, sob a direção de um partido, deveria buscar construir sua plena hegemonia em direção ao socialismo. Todos estes elementos, no cômputo geral, foram decisivos para a Revolução de 1917.

\section{Lenin e a questão agrária na Revolução Russa de 1917}

Processada uma década desde a derrota de 1905, a Rússia voltou a presenciar um processo revolucionário em 1917. Em fevereiro daquele ano, enfim derrubou-se a multissecular autocracia czarista, que acumulou um conjunto de desgastes em função das promessas feitas e não cumpridas após os levantes de 1905, a exemplo da convocação de uma Assembleia Constituinte. Sua legitimidade - a do czarismo - estava no limbo e as ações que conduziram à sua derrubada foram em grande parte preparadas pelos soldados do país, cuja maioria era camponesa. Como desdobramento da derrubada do czar, instalase um governo provisório hegemonizado pela burguesia liberal e encabeçado por Aleksandr Keriénski.

À época Lenin estava exilado. A conjuntura internacional, por sua vez, estava agitadíssima face à Primeira Guerra Mundial, iniciada em 1914, que também causava interferências sobre a vida social russa. O debate no movimento revolucionário internacional estava, de igual modo em função da guerra, esquentadíssimo. A social-democracia alemã (representada pelo SPD) havia votado favoravelmente à aprovação dos créditos de guerra e isto causou, com razão, imensas conturbações nas organizações de trabalhadores em diversos países. Nesse contexto, Lenin decifra que a humanidade estava a assistir uma transição de monta no interior do próprio modo de produção capitalista: sua passagem a um novo estágio, superior, dominado pelos monopólios e pelo capital financeiro. Esta tese, brilhantemente desenvolvida no clássico Imperialismo, estágio superior do capitalismo (redigido em 1916, publicado em 1917), forneceu ao seu autor - e, após sua publicação, ao conjunto dos trabalhadores e suas organizações melhores condições para apreender a fundo não somente o significado daquela guerra, mas da nova qualidade adquirida pelo modo de produção predominante.

$\mathrm{Na}$ Rússia, com a instalação do governo provisório, parte dos dirigentes do movimento revolucionário (dentre eles Lenin), regressam de um longo período de exílio e encontraram no país uma efervescência popular significativa. Uma situação nova estava colocada aos bolcheviques, afinal de contas, 
até 1917, o centro de sua estratégia era a derrubada do czarismo. Ora, o czarismo havia sido deposto. Qual seria, então, o próximo passo?

De início, a posição mais consensual no interior do movimento socialista russo (e mesmo entre os bolcheviques) é de apoio ao governo provisório, tendo em vista sua instalação recente, sua plataforma democrática, sua força social de massas. Em seu retorno, Lenin ([1917] 2017) insere - para muitos talvez até inesperadamente - uma polêmica de relevo ao enfatizar que a força dirigente do proletariado (o partido) deveria acelerar ao máximo a tomada do poder de Estado por meio de sua própria organização. Esta é uma entre as Teses de Abril. Àquela altura, Lenin estava convencido de que a revolução democrático-burguesa estava consumada na Rússia e que em função disso era necessário redefinir as táticas e a estratégia dos revolucionários.

Não foi à toa que Lenin chegou a esta conclusão. $\mathrm{O}$ ânimo das massas era evidente, por um lado e, por outro, a frágil burguesia liberal daquele país não dispunha de condições ou vontade política para dar consequência a um programa com o qual aparentemente havia se comprometido. Meses se passaram e o governo provisório nem tirava o país da Guerra, nem realizava reforma agrária, nem convocava Assembleia Constituinte. Uma pergunta então se faz preponderante: por quê?

Para Lenin, as movimentações da burguesia liberal no governo, sempre escorregadias, traduziam uma pactuação com a derrotada dinastia dos Romanov. Noutros termos, o governo comandado pela burguesia e pelos latifundiários que haviam se transformado em burgueses estava substancialmente comprometido com o grande capital e com negociatas políticas e econômicas com a referida dinastia. Deste modo, as condições e mesmo os argumentos eram suficientes para atacar politicamente o governo provisório. Em paralelo a ele, os soviets, que eram conselhos auto-organizados de operários, camponeses e soldados, passaram a obter uma importância cada vez significativa ao ponto de constituir-se, de fato e conjunturalmente, uma dualidade de poderes na Rússia: de um lado, a ditadura da burguesia; de outro, a ditadura democrática operário-camponesa. Era preciso então avançar, e nas Teses de Abril Lenin ([1917] 2017) lança a palavra de ordem "Todo poder aos sovietes!", estimulando e em seguida provocando uma inflexão na tática das forças revolucionárias.

O movimento histórico confirmou o acerto da proposição de Lenin. O que estava no centro, ali, era sobremodo a questão do Estado. De abril em diante, os bolcheviques e sua influência político-social cresceram em proporções extraordinárias. Segundo Hobsbawm (1995), o partido em pouco tempo passou a ter cerca de 250 mil militantes. Isto se deve, em larga medida, às formulações nas referidas teses no que diz respeito à questão agrária e camponesa. Processou-se uma revisão do programa agrário do POSDR, amplamente determinado pela mobilizadora síntese "Pão, paz e terra". Assegurou Lenin:

Devemos exigir a nacionalização de todas as terras, isto é, a passagem das terras existentes no país para a propriedade do poder central do Estado. Este poder deverá determinar as proporções, etc., do fundo de colonização, promulgar as leis para a proteção florestal, melhoramento do solo, etc. e proibir em absoluto toda mediação entre o proprietário de terra, o Estado, e o seu arrendatário, o agricultor [...]. A 
disposição da terra [...] deve encontrar-se [...] plena e exclusivamente nas mãos dos soviets. (LENIN, [1917] 2017, p. 33).

Esta posição embasava-se, ainda, no entendimento de que aquele poder dual logo se esgotaria, tendo em vista que, na prática, é inviável a existências de duas formas organizativas opostas no interior de um mesmo Estado. A coexistência temporária entre a ditadura da burguesia e a ditadura democrática operário-camponesa apenas expressava um momento de transição, o que também veio a se confirmar. Em julho de 1917, em diversas regiões da Rússia, ações massivas ganham lugar e fazem com que o governo provisório, uma vez com as forças da repressão estatal em mãos, as utilize contra o povo em luta. Entre julho e o fim de agosto a repressão aumenta e, mais uma vez, um realinhamento da tática: Lenin propõe que se inicie de imediato uma insurreição armada que tenha por objetivo a tomada revolucionária do poder, esboçada em outro clássico texto escrito no calor da hora, em setembro daquele ano: O Estado e a revolução (LENIN, [1917] 2010).

A revolução socialista enfim triunfa em outubro de 1917. Ela veio a ser, face seu significado, um dos principais acontecimentos do "breve século XX" (HOBSBAWM, 1995). Por meio dela a Rússia ingressou num novo momento de sua história e decisivamente influenciou o movimento comunista mundial, tornando-se uma referência e sugerindo a possibilidade de que a revolução poderia (e pode) ocorrer em todo o mundo. Aboliu-se, então, a propriedade privada dos meios de produção, realizou-se uma ampla reforma agrária, os bancos foram estatizados, os sistemas de saúde e educação foram radicalmente reconfigurados, dentre outras conquistas civilizatórias, a exemplo do aborto legal e da autodeterminação dos povos

É preciso considerar, todavia, que a tomada revolucionária do poder de Estado arrasta consigo um gigantesco trabalho. O período 1917-1920, em particular, foi de extremas dificuldades. Enormes eram as tarefas e grandiosa teria de ser a habilidade política para manter e fazer avançar a revolução em um país devastado pelos efeitos da guerra. No campo, então, a situação era dramática: a crise de abastecimento transformava a fome em grave problemática. Ainda assim, em 1918, como resultado da aliança operáriocamponesa, o caráter socialista da revolução afirma-se também no campo. O ano de 1918, aliás, foi de escuta dos camponeses por parte do Estado proletário e, em especial e sem romantismos, por parte de Lenin. Em consequência, naquele ano adotou-se a linha política de manutenção da aliança com os camponeses pobres e eliminação completa da burguesia rural (kulaks). O encaminhamento obteve materialidade: os camponeses apossaram-se das terras dos grandes proprietários e as distribuíram em unidades menores.

Com questões alimentares e produtivas pendentes, um ano depois, em 1919, os bolcheviques também incluem em sua agenda política o apoio aos camponeses médios, partindo do entendimento de que era preciso disputá-los. Os revolucionários estavam, em suma, a busca de construir melhores condições econômicas no país, o que resultou, a partir de 1921, em uma nova política econômica, a NEP, cuja política agrária e agrícola foi marcada pelo crescimento de cooperativas que, embora coletivas, permitia a participação dos médios produtores, repondo em outros termos a aliança operário-camponesa. 
Com o desenvolvimento da revolução, a prospecção de Lenin era a plena coletivização da propriedade da terra. No documento intitulado Teses sobre a tática do PC Russo, de 1921, ele afirma que é preciso "[...] manter uma aliança firme com ele [o campesinato] para percorrer as numerosas etapas sucessivas conducentes à coletivização total da agricultura." (LENIN, [1921] 2012, p. 62). Do seu ponto de vista, a solução em definitivo da questão agrária na Rússia compreendia a cooperação socialista que, por sua vez, deveria assumir o caráter de empresa coletiva socialista assentada no princípio da adesão voluntária. Evidentemente não teremos condições de aqui explicar em detalhes a reforma agrária levada adiante pela Revolução Russa e pela União das Repúblicas Socialistas Soviéticas (URSS) ${ }^{16}$. Convém apenas pôr em relevo, de modo breve, que a Rússia experimentou, sim, uma ampla coletivização da propriedade rural através do regime de colcoz, que transformou a vida dos camponeses da Rússia, elevando suas condições de vida e trabalho e assegurando, além de impulsionar o pleno desenvolvimento agrícola em bases agroindustriais modernas.

Enfim, pouco antes de sua morte, em novembro de 1922 (Lenin falece em janeiro de 1924), quando da realização do IV Congresso da III Internacional e passado o pior dos piores no que diz respeito à reconstrução da Rússia no pós-guerra, ele já observava extraordinárias conquistas obtidas pela revolução no campo. No relatório por ele apresentado no Congresso registra-se o seguinte: “[...] num ano [entre 1921 e 1922] o campesinato [...] venceu a fome [...]. As insurreições camponesas que antes, até 1921, constituíam por assim dizer um fenômeno geral na Rússia, desapareceram quase por completo. $\mathrm{O}$ campesinato está satisfeito com a situação. Isto podemos afirmar tranquilamente." (LENIN, [1922] 2012, p. 76). Há estudos, os quais não teremos condições de recorrer aqui, que apresentam entrevistas feitas com os camponeses no contexto posterior à Revolução (Sousa, 2017). Os relatos, no geral, são úteis para confirmar o seguinte: com a Revolução de Outubro e suas conquistas, o conjunto do povo daquele país, os edificadores de tamanhas mudanças, abriram na história da sociedade moderna a certeza de que é possível e necessário romper as amarras da exploração e da dominação. Este é um legado e uma lição.

\section{Considerações finais}

Em vista do apresentado, podemos concluir que a questão agrária atravessa a trajetória de Lenin, fazendo-se presente tanto em sua reflexão teórica quanto em sua ação política revolucionária. Nele o tema é sobretudo tratado em perspectiva histórica, em torno da qual combinam-se, com rigor teóricometodológico, diferentes graus de abstração: em maior grau de abstração, as leis gerais que regem o modo de produção; em maior grau de abstração, as particularidades de uma determinada formação econômicosocial.

Neste sentido, o legado deixado por Lenin carece de estudo e investigação por parte das gerações atuais que se dispõem a interpretar historicamente a questão agrária e mesmo o desenvolvimento da sociedade moderna. Seu exercício criativo legou, sem dúvidas, interpretações que não se esgotam à particularidade russa pois também possuem uma universalidade. Embora execrado por muitos, Lenin tem 
muito a contribuir com a formação humana em suas mais diferentes áreas. Mesmo entre os nossos, no marxismo, seu pensamento é atacado por muito, em especial os que em demasia se agarram a certo academicismo. A consequência disto, ao que nos parece, recai não somente sobre a dimensão intelectual, pois tende, ao mesmo tempo, a refutações da dimensão política contida no marxismo. E excluir a política do marxismo é uma contradição em termos.

Neste texto, nosso esforço limitou-se a apresentar apenas elementos gerais capazes de fornecer uma visão panorâmica da interpretação lenineana da questão agrária e, para atender a este fim, tentamos combinar o desenvolvimento da obra aos acontecimentos históricos da Rússia. Sobressaíram-se, nesse âmbito, a identificação dos caracteres gerais do Império Russo, do processo de formação do mercado interno e da grande indústria naquele país, da original concepção de aliança operário-camponesa e de como esta se fez presente na experiência concreta da Revolução Russa de 1917. Por força de nosso objetivo, não concentramos atenção analítica a um conjunto de polêmicas que constitui este debate. Nos interessa, com este texto, socializar com seus leitores uma visão geral que possibilite uma apreensão mais ampla da reforma agrária sob a ótica de um dos mais expoentes teóricos marxista de todos os tempos. Que o sesquicentenário de Lenin, enfim, sirva-nos de inspiração para revisitar sua obra e dela extrair ensinamentos. Muita coisa mudou em um século e a história está aí para provar. Mas Lenin sempre tem algo de importante a dizer.

\section{Referências:}

CARVALHO, Horácio Martins. A questão agrária e o campesinato na revolução russa de 1917. In: Boletim DATALUTA, n. 115, São Paulo, 2017.

COUTINHO, Ronaldo. Introdução. In: LENIN, V. I. Esquerdismo, doença infantil do comunismo. São Paulo: Expressão Popular, 2013.

FERNANDES, Florestan. Introdução. In: FERNANDES, F. (org.). Lenin: política. São Paulo: Ática, 1978.

GRUPPI, Luciano. O pensamento de Lenin. Rio de Janeiro: Graal, 1979.

HOBSBAWM, Eric (org.). História do marxismo. Vol. 5. Rio de Janeiro: Paz e Terra, 1985.

HOBSBAWM, Eric. A era dos extremos: o breve século XX. São Paulo: Companhia das Letras, 1995.

LEFEBVRE, Henri. La pensée de Lénine. Paris: Bordas, 1957.

LENIN, Vladimir Ilitch. O programa agrário da social democracia na primeira Revolução Russa de 1905-1907. São Paulo: Livraria Editora Ciências Humanas, 1980.

LENIN, Vladimir Ilitch. Teses de abril. São Paulo: Boitempo, 2017.

LENIN, Vladimir Ilitch. O desenvolvimento do capitalismo na Rússia. São Paulo: Abril Cultural, 1982.

LÉNINE, Vladimir Ilitch. Aos pobres do campo. Lisboa: Avante, 1984.

LENIN, Vladimir Ilitch. Que fazer?: problemas candentes do nosso movimento. São Paulo: Expressão Popular, 2010. 
LENIN, Vladimir Ilitch. Imperialismo, estágio superior do capitalismo. São Paulo: Expressão Popular, 2012.

LENIN, Vladimir Ilitch. Lenin e a questão agrária (1917-1922). São Paulo: Portal, 2012.

LUKÁCS, György. Lenin: um estudo sobre a unidade de seu pensamento. São Paulo: Boitempo, 2012.

MARX; Karl; ENGELS, Friedrich. A ideologia alemã. São Paulo: Boitempo, 2007.

MEDEIROS, Evelyne; BEZERRA, Lucas. Considerações sobre o desenvolvimento desigual e combinado no capitalismo brasileiro. In: MEDEIROS, Evelyne; NOGUEIRA, Leonardo; BEZERRA, Lucas. (Orgs.). Formação social e serviço social: a realidade brasileira em debate. São Paulo: Outras Expressões, 2019.

NETTO, José Paulo. Introdução. In: LENIN, V. I. O desenvolvimento do capitalismo na Rússia. (Tradução de José Paulo Netto). São Paulo: Abril Cultural, 1982.

OSÓRIO, Ligia. Lenin: a questão agrária na Rússia. In: Crítica Marxista, n. 35, São Paulo, 2012.

PRESTES, Zoia; PRESTES, Ana. A experiência soviética dos colcozes. In: STÉDILE, João Pedro. (Org.). Experiências históricas de reforma agrária no mundo. São Paulo: Expressão Popular, 2020 [no prelo].

SKAZKINE, Serge. Problemas fundamentais da "segunda servidão" na Europa Central e Oriental. In: Crítica Marxista, n. 36, São Paulo, 2013.

SOUSA, Ramsés Eduardo. Lênin, os camponeses e a revolução russa. In: Revista do Departamento de História e do Programa de Pós-Graduação em História do Brasil da UFPI. Teresina, v. 6, n. 1 jan./jun. 2017.

\footnotetext{
Notas

1 Assistente Social. Doutorando em Serviço Social pela UFRJ. Currículo Lattes: http://lattes.cnpq.br/6304680071717288. E-mail: lucasbezerra.1917@gmail.com; ORCID: http://orcid.org/0000-0002-1297-2224

2 "Dias e noites de amor e de guerra". São Paulo: L\&PM, 2001.

3 Algumas obras sistematizam os principais aspectos centrais da biografia e do pensamento de Lenin, dentre estas Gruppi (1979), Hobsbawm (1985) e Lefebvre (1957).

${ }^{4} \mathrm{O}$ exílio acadêmico de Lenin foi tema de importantes elaborações do professor Ronaldo Coutinho. Cf. Coutinho (2013).

5 A este respeito, ver Skazkine (2013).

${ }^{6}$ In: Relatório sobre a Revolução Russa de 1905. Disponível em: https://www.marxists.org/portugues/lenin/1917/01/22.htm. Acesso em 23 jul. 2020.

${ }^{7}$ Os populistas caracterizam-se como tal, na análise lenineana, em face dos seguintes problemas teórico-políticos: “i) considerar o capitalismo na Rússia como uma decadência, uma regressão...; ii) considerar original o regime econômico russo em geral e o camponês com sua comunidade [...], em particular [...]; iii) ignorar as relações entre a "intelectualidade" e as instituições jurídicopolíticas do país, por um lado, e os interesses materiais de determinadas classes sociais, por outro." (NETTO, [1979] 1982, p. 13 14).

8 "O mercado interno aparece quando aparece a economia mercantil: ele é criado pelo desenvolvimento dessa economia e é o grau de fragmentação da divisão social do trabalho que determina o nível desse desenvolvimento. O mercado interno se amplia quando a economia mercantil passa dos produtos à força de trabalho, e apenas na medida em que esta última se converte em mercadoria o capitalismo cobre toda a produção do país, desenvolvendo-se graças sobretudo à produção de meios de produção que ocupam um lugar cada vez mais importante na sociedade capitalista. [...] O grau de desenvolvimento do mercado interno é o grau de desenvolvimento do capitalismo no país. É incorreto colocar a questão dos limites do mercado interno independentemente da questão do grau de desenvolvimento do capitalismo - como fazem os economistas populistas." (LENIN, [1899] 1982, p. 33).

9 "A necessidade do mercado externo para um país capitalista não é, em absoluto, determinada pelas leis da realização do produto social (e da mais-valia, em particular), mas, primeiramente, pelo fato de que o capitalismo resulta de uma circulação de mercadorias largamente desenvolvida, que ultrapassa os limites de um país. Um país capitalista sem comércio exterior é impensável - e, aliás, não existe.” (LENIN, [1899] 1982, p. 30).
} 
10 “[...] capitalismo não pode ter um desenvolvimento uniforme na agricultura (nem na indústria): num lugar (num país, numa região, nem estabelecimento agrícola) ele faz progredir um ramo da economia rural; noutra região, impulsiona outro ramo etc." (LENIN, [1899] 1982, p. 204).

11 "Boa parte dos erros cometidos pelos escritores populistas decorre do fato de eles tentarem provar que esse desenvolvimento desproporcional, aleatório, aos saltos, não é desenvolvimento" (LENIN, [1899] 1982, p. 373).

12 As mudanças relacionadas ao trabalho servem-nos de ilustração. Com o considerável definhamento das mais tradicionais relações sociais naquela sociedade, o "pagamento em trabalho" e a dependência pessoal do camponês tornaram-se cada vez mais raras.

13 '[...] as migrações oferecem vantagens 'puramente econômicas' aos operários, porque eles se dirigem para locais onde os salários são mais elevados e onde é mais vantajosa a sua situação de vendedores da força de trabalho. Por mais simples que seja essa consideração, ela é esquecida com excessiva frequência pelos que pretendem observar as coisas de um ponto de vista superior, dito 'econômico-nacional”'. (LENIN, [1899] 1982, p. 160).

14 “[...] os artigos de consumo desempenham, na formação do mercado interno, um papel menor que os meios de produção [...] A contradição que existe entre a tendência ao ilimitado crescimento da produção e o consumo limitado não é a única do capitalismo, que só pode existir e se desenvolver em meio a contradições. Elas, aliás, atestam o caráter historicamente transitório do capitalismo." (LENIN, 1982, p. 26).

15 "Partido pequeno-burguês russo [...] Não viam as diferenças de classe entre o proletariado e o campesinato, obscureciam a diferenciação de classe e as contradições dentro do campesinato, rejeitavam o papel dirigente do proletariado na revolução" (LÉNINE, [1903] 1984, p. 86-87).

${ }_{16}$ Cf. Prestes e Prestes (2020). 